\title{
Institutionalizing Islamic Banking: The Case of Bank of Khyber, Pakistan
}

\author{
Muhammad Mohsin Khan ${ }^{1 *}$, Muhammad Atiq ${ }^{2}$, Karim Ullah ${ }^{3}$ \\ ${ }^{1}$ Director, Institute of Management Sciences, Peshawar, Pakistan \\ ${ }^{2}$ Assistant Professor, Institute of Management Sciences, Peshawar, Pakistan \\ ${ }^{3}$ Founding Head of Centre for Excellence in Islamic Finance, Institute of Management \\ Sciences, Peshawar, Pakistan
}

\section{Keywords}

Islamic Banking

Financial Intermediation

Institutional Theory

\begin{abstract}
This article discusses the move for conversion of a conventional bank into Islamic one taking the Bank of Khyber (BoK), Pakistan as a case study. It provides an in-depth and emprical narrative of how Islamic banking has been introduced at the Bank of Khyber particularly motivated by political and social incentives to reconstruct the current conventional banking model. Initially, BoK was operating on conventional model of financial intermediation and gradually, an Islamic banking division, a Shari 'ah Board, and multiple Islamic depository and financing processes have been introduced and institutionalized to establish social and political legitimacy within the context. This case highlights the core challenges to the BoK team and value creation of the institutional intervention, particularly shared value creation and collaborative efforts across the industry, from an institutional theory perspective. This case carries multiple implications for the Islamic banking professionals and offers practical insights on the process of business model reconstruction within the context of Islamic banking.
\end{abstract}

KAUJIE Classification: H13, I2, J0

JEL Classification: G2

(C) 2018 JIBM. All rights reserved.

\section{Institutionalization and Institutional Theory}

\section{INTRODUCTION}

Institutional theory focuses on institutional pressures and how firms give into those pressures to adapt to social initiatives to gain legitimacy. The BoK was facing the challenge to incorporate Islamic finance as political and social pressures exacerbated for the above mentioned purpose. Companies, such as, BoK adjust their business models, processes, and products to adjust to institutional pressures to create value for themselves and their stakeholders. Institutional forces, by exerting their influence, bring changes in the business environment, thus leading to increasing homogenization of business practices, processes

\footnotetext{
*Corresponding author: Muhammad Mohsin Khan

†Email: Muhammad.mohsin@imsciences.edu.pk
} 
and products across and within industries (Campbell, 2007; DiMaggio \& Powell, 1991). By conforming to the demands of the institutional actors, companies attempt to gain legitimacy, which is defined by Suchman (1995) as the "generalized perception or assumption that the actions of an entity are desirable, proper, or appropriate within some socially constructed system of norms, values, beliefs, and definitions" (p. 574). A socially and professionally legitimate organization is not only considered more trustworthy, but also more predictable and carries more meaning for the stakeholders. However, to become a legitimate organization, an entity must adopt the relevant rules, regulations, and practices that institutional actors permeate through an industry and/or across industries. Therefore, a legitimate organization is the one which is more flexible, adoptive, and agile. In this case, BoK was facing institutional pressures to innovate its business model for incorporating Islamic banking.

The institutional theory, described in this article, appears to provide an appropriate theoretical lens through which the motivations and pressures to adopt Islamic banking can be examined well. BoK seems to establish legitimacy to two wider groups of stakeholders: those considering conventional banking as illegitimate model, and those considering Islamic finance as socially more acceptable and therefore legitimate model of engaging in banking business. To promote financial inclusion, international lenders asked the regulator to promote Islamic banking and to come up with the required regulations for it as, Islamic banking is in alignment with the normative standards and religious beliefs of the societal members (SBP \& DFID, 2014). Pakistani nation as a whole has also been pressuring the Government and the Central Bank to introduce Islamic banking in the country. Accordingly, after a long effort and spadework, Islamic banking has been introduced and promoted in Pakistan and particularly in KPK province, where the public is believed to be having a high faith sentiment related to Shari' 'ah compliance, particularly freedom from payment and charge of interest. The next section provides an account of how Islamic banking was introduced into the core operations of the BoK, in order to develop narrative-emprical answers to the following questions:

- How Institutional theories work in introducing a social and political intervention to adapt a conventional model to a new ideological model, using Islamic banking as case.

- What problem practitioners may face in adopting a business models particularly related to understanding and making the stakeholders understand about Islamic banking model.

- What is the role of collaboration in gradually reducing uncertainty by way of knowledge acquisition and later, its implementation in the market.

\section{The Initiative of Islamic Banking at BoK}

The Bank of Khyber is a provincial government bank owned by Government of Khyber Pakhtunkhwa (KPK) and based in Peshawar, Pakistan, with 150 branches all over the country. It was set up as a state-owned, regional bank in 1991 through Act No. XIV, passed by the Provincial Legislative Assembly of the Khyber Pakhtunkhwa Province of Pakistan. It was awarded status of a scheduled bank in September 1994. The Bank of Khyber enjoys a unique position, and stands out amidst the other banks operating within Pakistan, and has the privilege of being bracketed amongst the only five government banks in the country. 
Currently, about 50\% branches are offering Islamic banking services in almost all parts of the country, with focus on the KPK itself.

It was 2003, when the Bank of Khyber, which was established in 1991, initiated Islamic banking. Looking at the long-standing demand of the people of the province, BoK was thinking of Islamic banking as one of its product even in the begining. But then there came a political influence, when a joint religious parties Government, called Mutahidah Majlis $e$ 'Amal (MMA), came to the power. Particularly, the Jummat Islami had a major role in the coalition government, and it is important to note that the provincial finance ministry was under them. The MMA was a political alliance consisting of Islamist, religious, and far-right parties of Pakistan. MMA was not just interested to start Islamic banking but also wanted to boost it, as part of Islamizing the economy of KPK at that time. Since the BoK was owned by the Government of KPK, it was directed to start Islamic banking immediately and thus the Government used its institutional power to bring change in the economic landscape of the province. This was long due as MMA had secured majority votes in the 2002 general elections based on promises that it will Islamize the whole system if the masses of Khyber Pakhtunkhwa voted for MMA. So, the MMA led Government approached Islamizing BoK as a ripe opportunity to show some tangible progress on their pre-election promises.

\section{Preparation of Islamic Banking Model and Knowledge Diffusion}

In a hig level meeting held in September, 2001, it was decided that the shift to interest free economy would be made in a gradual and phased manner and without causing any disruptions. Thus, a policy decision was made to develop Islamic banking in parallel with the conventional banking (Janjua, 2004). Accordingly, the State Bank issued detailed criteria in December 2001 for establishment of various categories of banks in the private sector. A three-pronged strategy was adopted by SBP including a) setting up a new full-fledged commercial bank to carry out exclusively banking business based on proposed Islamic products, b) setting up subsidiaries by the commercial banks for the purpose of conducting Shari'ah compliant transactions; and c) specifying branches by the commercial banks exclusively dealing in Islamic products.

The BoK had been directed to prepare Islamic banking model within the conventional banking model and immediately start Islamic banking, to be more legitimate in the context. The first author of this case, working as an Executive Vice President (EVP) at the time, studied various Islamic banking models from worldwide to adopt, and consulted many Shari'ah scholars). At that time, Meezan Bank was the leading full-fledged Islamic bank, which was operational, so BoK analyzed Meezan Bank's model as well. Some seminars were also held to establish a general awareness among the BoK staff regarding Islamic banking. The management of BoK noticed that introduction of Islamic banking was not just a political demand of the MMA led Government, but globally and locally the demand for having Islamic banking was growing, as was particularly witnessed in the Middle East and the Far East, particularly Malaysia at that time.

Innovation, of any sort, requires acquisition of knowledge to reduce uncertainties and allow for calculated risk-taking in the market based on the knowledge acquired (Plessis, 
2007; Quintane, Casselman, Reiche, \& Nylund, 2011). Therefore, BoK did a preliminary research on Islamic banking systems in a few Islamic countries, particularly approaching the research from the vantage point of adopting it to the requirements of the Pakistani market. After conducting the research and gaining knowledge, it was time to implement the lessons learned so far. The management of BoK took a calculated risk of introducing business model reconstruction by starting its first Islamic branch in 2003 in Karkhano market of Peshawar, which is a big market of faith-centric customers. For that, BoK got permission from SBP and also got guidance from SBP regarding the initiation of first Islamic branch.

As indicate above, the SBP announced the three models of Islamic banking as given below:

TABLE 1

Models of Islamic banking

\begin{tabular}{ll}
\hline \hline Islamic Banking Models & Description \\
\hline Islamic Commercial Bank & $\begin{array}{l}\text { This type of banking only offers products and services } \\
\text { according to the laws of Shari'ah. Annexure-I to IBD }\end{array}$ \\
& $\begin{array}{l}\text { Circular No. 02 of 2004 describes the criteria for setting } \\
\text { up Islamic commercial banks. }\end{array}$ \\
\hline
\end{tabular}

Islamic Banking Subsidiary Commercial banks may set up subsidiaries for the purpose of conducting Shari'ah compliant transactions. Islamic Subsidiary operates on the strength of the Parent Bank, which is the conventional bank. The model used is still a leveraged model, but the Islamic Subsidiary can choose which services or function they want to "outsource" to the conventional bank. SBP's criteria for setting up Islamic banking subsidiary is explained in BPD Circular No. 01 of 2003.

Islamic Banking Branches Specifying branches by the commercial banks exclusively dealing in Islamic products. Stand-alone. Islamic banking branches are based on Islamic principles operated via conventional banks. SBP's criteria for setting up Islamic banking branches is described in BPD Circular No. 01 of 2003 .

\section{The Initial Success}

BoK started its first Islamic branch and within a few months, that branch was in profits too which was unusual in normal banking practices. Profits were rightly due as the branch already had interest-free deposits in Current Accounts from the businessmen in the Karkhano area, as they did not want interest payments on their deposits. In this way, the branch had very low cost of funds and then those funds were invested and the branch started earning good profits. Thus, the initial risk taken by the management of BoK had paid off well and it was time to capitalize on the initial success by applying the new business model to other branches as well. Later on, looking at the growth in Islamic banking, the response of the market, and 
the Government's intentions to Islamize the economy through the Bank of Khyber at that time, the bank started to open more branches. By then, BoK had developed a formal advisory board as well, which comprised of well reputed Islamic scholars of that time, and they were all helping the bank to move towards the Islamic banking and were aspiring to Islamize the economic system as well.

At that time, the Managing Director (MD) of BoK had the main role because he was guiding and supervising the bank in its operations. In the Islamic banking division of BOK, people with Islamic banking experience were hired and help from Meezan Bank was also sought at that time. The initiative of hiring Islamic banking professionals and the collaborations with Meezan Bank and SBP, helped in gradually reducing the uncertainties and the business model reconstruction became a learning process for everyone within the BOK. Both SBP and Meezan Bank were very helpful in facilitating trainings and knowledge diffusion, and the innovation in business model due to political and social pressure to introduce Islamic finance. The move was successful and there was growing acceptance and legitimacy of the adapted model within and outside the bank. Organizational effectiveness is a function of knowledge management (Zheng, Yang, \& McLean, 2010) and BoK was effective in that it managed its knowledge well through its collaborations and an agile and flexible approach towards business model reconstruction opportunity.

\section{Initial Problems}

Success for the BoK did not come without encountering some problems though. For instance, in the first branch the customers had their deposits in current accounts because they did not want to take interest according to their religious beliefs. When they applied for financing facility, they thought that financing would be free as well. They were told that they will have to pay some administrative charges to the bank and the business model of the bank is such in which the bank would purchase some goods and assets, resell or lease them, will get return and thus may share profits with the depositors.

The customers maintaining Current accounts generally were not ready for this and were shocked to know about Islamic banking: on deposits, the bank does not give them any profits, while for providing financing facility, the bank wants to share profits. It is because they were not aware of the Islamic banking model being followed. Perhaps, at the time of deposit generation, the BoK should have introduced profit oriented deposits with business models, such as mudārabah, rather than the qard model and should have communicated about profit sharing on financing facility as well. Effective adaptation to a new business model requires that full knowledge be diffused to the stakeholders, especially the customers and the employees, so that the new venture operates smoothly. It suggests that there was a missing link between the customers at Karkhanu market and the BoK that must have been taken into consideration in the very beginning by any effective awareness scheme.

As a response, the bank started some seminars and awareness programs so as to make customers aware that both financing and deposits are not free, and there are ways of giving profits according to the Islamic rules, using various business models such as mushärakah, mudāarabah, murābahah, ijārah (e.g., Ullah \& Al-Karaghouli, 2017), which were approved 
by the Shari' 'ah board of the BoK.

\section{Collaboration and Institutional Interventions}

For making the Islamic banking model to work, trainings, orientation and facilitation were provided by SBP (the regulator), regarding Islamic Finance. Meezan Bank also played a pivotal role in the collaborative efforts because at that time Meezan Bank was first bank with fully Islamic banking operations and Shari' 'ah Board in the country. So, they helped by giving access to their board members such as the likes of Mufti Taqi Usmani, who at that time was the member of the Shari 'ah Supervisory Committee of the BoK as well, interactions with whom were instrumental in making BoK's new business model successful too as they provided BoK with the essential knowledge required for developing and implementing the Islamic banking model. BoK's management had full support of the MMA led Government of KPK who's own motive, as discussed earlier, was to secure their vote bank for the future. For BoK, the whole process was about knowledge acquisition to reduce its own uncertainties regarding the new initiative. Another important component of this collaborative process and institutional intervention was to put the acquired knowledge to work in the market, which was professionally executed by the management of BoK, as was evident from the initial success. Nevertheless, it was a regular and ongoing process of knowledge acquisition and putting it to work by improving the Islamic modes of financing and making it more aware to the people of the province. Morris, Kuratko, and Covin (2008) contend that for an organization to be innovative, it needs to be adaptable and flexible. Adaptability and flexibility refer to the capacity to adjust and the capacity to innovate operational methods and strategies to changing environmental conditions without disturbing the core operations and processes (Morris et al., 2008). Thus, BoK was both adaptable and flexible in dealing with the business model reconstruction opportunity created by institutional intervention through its knowledge management and collaborative practices.

\section{Value Creation}

Due to the efforts and institutional interventions across the industry described above, some benefit was being realized, which was that people of the province started believing that banking could be done in an Islamic way. Value creation in one sense was that those people who were out of the banking system because of their religious beliefs and values, they started banking and thus, there was more financial inclusion as a result of BoK institutionalizing the Islamic financial services. This value creation was especially important from the point of view of international institutions, who have been working for reducing exclusion and enhancing financial inclusion. People from different cadres, some half-heartedly, some fully aware, that the practice BoK had adopted was really Islamic banking, joined the formal financial system and thus increase in financial inclusiveness was witnessed to some extent. Secondly, value was also realized by the BoK in the shape of growth in profits as it had access to low cost funds, which were further invested to earn significant returns. Thus, shared value (Atiq \& Karatas-Ozkan, 2013; Porter \& Kramer, 2011), i.e. both social and corporate value, were created as a result of business model reconstruction by BoK. 


\section{CONCLUSION AND FINDINGS}

On the basis of the aforementioned discussion, we can conclude that institutional actors play an instrumental role in bringing about changes in an industry, in terms of practices and business model reconstructions, and their power to bring change emanates directly from the position they hold in and outside that industry. For instance, as noted above, MMA led Government's power to direct BoK to initiate Islamic banking, is a virtue of the power vested in them by the people of the province. While SBP as an institutional force, leverages its power directly from the role it plays as a regulator of the banking system. Moreover, it can also be concluded that to bring and to enact institutional changes such as Islamic banking, collaborative efforts, knowledge acquisition and awareness creation are critical, which again require input from the institutional forces. Through industry wide collaborative efforts, knowledge required for bringing institutional changes can be acquired, which reduces uncertainties and paves way for the pursuit of opportunities created by latent and manifest institutional pressures. Such collaborations and institutional interventions further lead to value creation, not only for society but as well as for incumbent firms like BoK, thus creating shared value. This case is an excellent example of how institutional actors and incumbent firms collaborate to further their agendas by bringing changes in an industry, the outcome of which is the creation of shared value.

This case has multi-fold implications for industry practitioners. Firstly, this case demonstrates that any service rendering firm should be flexible and agile enough to respond to the institutional pressures. This requires the firm to be entrepreneurial in its approach by focusing on the identification and exploitation of opportunities such institutional pressures create. Secondly, uncertainty reduction vis-a-vis business model reconstruction is a gradual process of knowledge acquisition and putting it to work in the market. Thirdly, knowledge acquired regarding the new practice, technology or product should be fully diffused to the stakeholders, in particular, employees and customers so as to avoid future complications and difficult situations, which involve distrust and the perception of being misled. Fourthly, opportunities created by institutional pressures require the incumbent firm to not only engage in intra-organizational collaboration but as well as inter-organizational collaboration so as to go down the learning curve quickly and avail its benefits.

\section{Analysis Questions}

- Describe the institutional pressures of BoK to introduce Islamic banking.

- Enlist and discuss the challenges that BoK faced in Institutionalising Islamic banking.

- How BoK reduced its uncertainty regarding business model reconstruction and launching of its first branch?

- What was the major mistake BoK had committed, which could have led to disastrous consequences, had timely action not been taken by the management? 
- If the BoK had not done any sort of collaboration, do you think the business model reconstruction would have been possible? Discuss your reasons.

- What are the other business opportunities available for BoK in today's scenario?

\section{Note to the Readers}

This narrative case article requires readings on Islamic finance, particulary, its institutional levels and the generic institutional theory, for which the following pre-requisit readings are suggested:

DiMaggio, P., \& Powell, WW. (1991). The new institutionalism in organizational analysis. Chicago, IL: University of Chicago Press.

Ullah, K., \& Al-Karaghouli, W. (2017). Understanding Islamic financial services: Theory and practice. London, UK: KoganPage. (Chapters 1-4).

\section{REFERENCES}

Atiq, M., \& Karatas-Ozkan, M. (2013). Sustainable corporate entrepreneurship from a strategic CSR (Corporate Social Responsibility) perspective: Current research and future opportunities. International Journal of Entrepreneurship and Innovation, 14 (1), 5-14. doi: https://doi.org/10.5367/ijei.2013.0102

Campbell, J. L. (2007). Why would corporations behave in socially responsible ways? An institutional theory of corporate social responsibility. Academy of Management Review 32(3), 946-967. doi: https://doi.org/10.5465/amr.2007.25275684

DiMaggio, P., \& Powell, W. W. (1991). The new institutionalism in organizational analysis. Chicago, IL: University of Chicago Press:

Janjua, M. A. (2004). History of the State Bank of Pakistan (Vol. 4 (1988-2003)). Karachi, Pakistan: State Bank of Pakistan.

Morris, M. H., Kuratko, D. F., \& Covin, J. G. (2008). Corporate entrepreneurship (2nd ed.). Mason, $\mathrm{OH}$ : Cengage Learning.

Plessis, M. D. (2007). The role of knowledge management in innovation. Journal of Knowledge Management, 11(4), 20-29. doi: https://doi.org/10.1108/13673270710762684

Porter, M. E., \& Kramer, M. R. (2011). Creating shared value: How to reinvent capitalismand unleash a wave of innovation and growth. Harvard Business Review, 89 (1), 63-77.

Quintane, E. R., Casselman, R. M., Reiche, B. S. \& Nylund, P. A. (2011). Innovation as a knowledge-based outcome. Journal of Knowledge Management, 15(6), 928-947. doi: https://doi.org/10.1108/13673271111179299

State Bank of Pakistan (SBP) and DFID. (2014). Knowledge, attitudes and practices of Islamic Banking (KAP Study). Retrieved from: http://www.sbp.org.pk/publications/KAPStudy.pdf

Suchman, M. C. (1995). Managing legitimacy: Strategic and institutional approaches. Academy of Management Review, 20(4), 571-610. doi: https://doi.org/10.5465/amr.1995.9508080331 
Ullah, K., \& Al-Karaghouli, W. (2017). Understanding Islamic financial services: Theory and practice. London, UK: KoganPage.

Zheng, W., Yang, B., \& McLean, G. N. (2010). Linking organizational culture, structure, strategy, and organizational effectiveness: Mediating role of knowledge management. Journal of Business Research, 63(7), 763-771. doi: https://doi.org/10.1016/j.jbusres.2009.06.005

$* * * * * * * * * * * * * * * * *$ 